\title{
Cuatro cuentos inconclusos
}

Para E.B.C.

El hombre, ese animal complejo, embustero, artificioso e impenetrable... Un filósofo es un hombre que constantemente vive, ve, oye, sospecha, espera y sueña cosas extraordinarias.

F. Nietzsche

El camino más cerca entre dos seres es el de la atracción apasionada.

Octavio Paz

\section{Tiempo de motel}

Al fin estaban alli. Ella se había salido con la suya. Lo había convencido de que el amor es algo que podía — que debía- materializarse. Que no se trataba -como él creía - de algo intangible, de algo sublime y etéreo. Cuando entraron a aquella habitación en desorden y con olor a otros cuerpos, ella casi pudo cantar victoria. Estaba segura de poder enseñarle sus dotes de mujer, de envolverlo con el calor de su cuerpo y la audacia de sus caricias. Se desnudó lentamente, con parsimonia. Quería que él se detuviera en ella, que la recorriera con la vista, que la deseara. El, impávido, no sabía qué hacer. No estaba convencido de que su amor, el amor que sentía por ella, fuera a salir más enriquecido después del contacto desnudo entre sus cuerpos. Temía que su amor se enturbiara, que, dominado por lo sentidos, se desnaturalizara y dejara de ser lo que hasta ese momento había sido: un enigma que anidaba en lo más profundo de sus entrañas. Ella era de la opinión de que el amor pasa por los sentidos, los olores y sabores del otro a quien se ama. Estaba segura - asi se lo había hecho saber a él- de que mientras no se fundieran en uno solo, mientras no exploraran cada parte de su cuerpo y no sorbieran lo más íntimo de cada uno de ellos, su amor 
sería una pura quimera, una pura fantasía, una pura ilusión. Allí estaban, desnudos uno frente al otro. El, con el firme propósito de hacer que su amor saliera incólume del desvarío de los sentidos. Ella, dispuesta a probarle que sólo por ese desvarío era que el amor que se profesaban podía valer la pena. Allí estaban. Petrificados uno frente al otro, observándose sin tocarse. De pronto, se escucharon un par de golpes sobre la puerta. Una voz les hizo saber que se había agotado el tiempo de uso de la habitación del motel.

\section{El misterio}

Cuando la vio por primera vez, supo inmediatamente que ella tenía un misterio que él tenía que descubrir. Se trató de un encuentro casual, de esos que suceden en el momento menos esperado y en las circunstancias más fortuitas. Pero ese día la tuvo delante de sí, con su enorme sonrisa y sus inmensos ojos claros. Ella apenas le dirigió la palabra o la mirada; los gestos, las miradas y las risas eran para otros. El, sin embargo, la observó detenidamente, se detuvo en su rostro, sus manos, su cabello, su boca. Escuchó hasta el último detalle de lo que ella decía, se fijó en cada énfasis y en cada inflexión de su voz. Trató de percibir su olor, pero otros olores se lo impidieron. Sin darse cuenta, una obsesión se estaba apoderando de él. No era una obsesión por ella, por conquistarla, por hacerla su amante. Eso lo tuvo claro desde el principio. Quería encontrar ese algo de donde emanaba el poder de seducción que ella irradiaba. El sabía que "eso" se encontraba en algún lugar de ella, aunque no tenía ni la más remota idea de dónde. Ni mucho menos tenía una idea aproximada de lo que podía ser. Se puso manos a la obra. Diseñó una estrategia que le permitiera explorar sus encantos para ver si era en ellos donde que se encontraba lo que buscaba. Pudo escuchar la sonrisa de ella, esta vez dirigida a él. Pudo escuchar sus bromas, observar una y otra vez sus gestos, sentir su mirada. Pero no tuvo suerte. Decidió acercarse más a ella, tocar su piel, sentir su olor. Con un poco de trabajo - -se valió de los artificios más ingeniosos - tuvo éxito en este propósito: logró tocarla y olerla. Pero el secreto de ella —su misterio según él- no apareció por ningún lado. Dispuesto como estaba a terminar lo que había comenzado decidió dar un último paso: explorar su sexo. Sabía que lo primero era lo primero y que para llevarla a la cama antes que nada debía dominarla a besos (de paso sabría si era en éstos que se encontraba lo que andaba buscando). La colmó a besos, ensayó los estilos más variados, sintió su lengua junto a la suya, pero no era en su boca donde debía buscar. Concluyó que el misterio de ella tenía que estar en su sexo. Y se puso, como en las otras ocasiones, manos a la obra. Y lo hizo, la llevó a la cama. La exploró con detalle, minuciosamente, una y otra vez tocó, olió, besó las profundidades de su cuerpo. Por unos instantes, mientras él se convertía en ella y ella en él, se olvidó del propósito que lo había llevado hasta allí. De pronto volvió a la realidad, se dio cuenta de que no había encontrado lo que buscaba. Una sensación de amargura y desazón se apoderó de él. Ella quizás 
no tenía ningún misterio y él quizás había perdido su tiempo en una búsqueda absurda. Mientras pensaba en lo estúpido de su empeño, en la pasión inútil que lo había agotado, ella, de frente al espejo, se ponía su sostén color azul. Tras detener la mirada en su espalda, pudo ver el contraste que hacían los tirantes del sostén sobre la piel clara de sus hombros. Una emoción intensa se apoderó de él, había encontrado el misterio de ella.

\section{Las ranas}

La atracción fue inmediata. Antes de esa mañana soleada de noviembre, no sabían absolutamente nada el uno del otro. Se miraron - se escrutaron- detenidamente, como queriendo conocerse total y plenamente en ese preciso instante. Procedian de dos mundos distintos, sus opciones vitales también lo eran. Ella, una viajera incansable, cuyas experiencias vitales se habian tejido en los lugares más remotos y extraños. El, un guardián de libros irredento, provinciano, enamorado de ese país minúsculo que lo había visto nacer y en el que estaba seguro moriría. La cultura de ella era sofisticada - no en vano habia sido alumna sobresaliente en una respetable universidad europea-. La cultura de él, por decir lo menos, era tosca, fragmentaria - había sido un alumno no tan bueno de una no tan buena universidad tercermundista-. Pero se gustaron irremediablemente. A él le atrajeron sus inmensos ojos claros, su sonrisa franca, su cabello rizado, la cadencia de sus gestos y la libertad de sus movimientos. A ella le gustó su mirada dulce y vivaz, su eterno humor, su vocación por el aislamiento y la soledad. Desde el primer instante los invadió la incertidumbre de no saber qué harian con lo que sentían. Un impulso que les nacia del alma les decia que debían tocarse, acariciarse, meterse el uno dentro del otro, fundirse en un solo cuerpo. No sabian como hacerlo, no tenían ni la más leve idea de cómo empezar, quién debía dar el primer paso o qué sucedería una vez que uno de los dos - o ambos - tuviera el valor de hacer la primera caricia, dar el primer beso o sujetar con el primer abrazo. Tenian miedo de lo que pudiera suceder con ellos; deseaban desesperadamente que sucediera algo. Emociones encontradas los dominaban, sentimientos confusos les quitaban el sueño, deseos incontrolables los empujaban a buscarse y encontrarse. Recordaban la pasión e intensidad del primer contacto entre sus labios. Nunca pensaron que el haberse convertido en ranas fuera un castigo por ese primer beso.

\section{Sueño}

La decisión de marcharse fue abrupta, tomada sin el menor dejo de reflexión. No sabía para dónde iba ni cuándo llegaría. Quizás lo que quería era salir de sí misma, huir, encontrarse. Tomó su mochila, un par de viejos zapatos tenis de la secundaria, un pantalón de mezclilla, desteñido y roto, un par de camisetas viejas, un cepillo dental. Total esos eran todos sus bienes desde que decidió mar- 
charse de casa de sus padres, cuando apenas iniciaba la universidad. Sus ahorros de toda la vida, su pasaporte, todo estaba en su lugar. Aquel país le pareció extraño y fascinante desde el primer momento. El calor, la gente, la comida, los olores, todo lo que estaba a su alrededor, todo lo que tocaba, olía y veía la hacían sentir viva. Se sentía ella misma, segura, llena de confianza, feliz. Nada le hacía falta. Dondequiera que iba era recibida con las mejores atenciones. Los hombres de aquel país remoto parecían embrujados cuando ella se reía con ellos o les dirigía la palabra. Era como si nunca hubieran visto mujer más bonita en su vida. Las mujeres de ese país remoto habían aceptado su preeminencia. No podía pedirle más a la vida. Era feliz como nunca lo había sido. La despertó el timbre del reloj despertador. Hostias se dijo a sí misma, son las 6:30 de la mañana y tengo que ver a dos clientes dentro de un par de horas. Repitió la rutina que había seguido desde que había quedado al frente de la oficina de abogados establecida por su difunto marido. $\mathrm{Al}$ momento de encender su coche - un mercedes azul, su color preferido - recordó el bonito sueño que había tenido. ¿O era acaso en ese instante que comenzaba a soñar?

Ciudad de México-Nueva Delhi, noviembre de 1999.

\section{Nota}

1. Escritor mexicano radicado en la India. 